\section{Impact of Using Transglutaminase Enzyme in Manufacturing Low and High Fat Mozzarella Cheese}

\section{Abstract}

A method for the use of transglutaminase enzyme (TG) in rennet coagulated cheese making was adopted. Rennet was added to milk at $5^{\circ} \mathrm{C}$ and kept for $30 \mathrm{~min}$, the TG was added and the mixture was left for $2 \mathrm{~h}$ before raising the temperature to $40^{\circ} \mathrm{C}$ for coagulation. The method was used for processing low and high fat mozzarella cheese with 2 levels of TG (0.02 and 0.05\%). The cheese was stored for 28 days at $5^{\circ} \mathrm{C}$ and the cheese chemical composition, functional properties and sensory attributes were determined. The addition of TG significantly increased cheese yield, moisture, fat and protein recovery and improved stretchability and meltability. In low fat cheese, the yield, stretchability and meltability increased by $8 \%, 40 \%$ and $50 \%$ in $0.02 \%$ TG cheese and $15.1 \% 60 \%$ and $66 \%$ in $0.05 \%$ TG cheese, respectively. In high fat cheese, the yield, stretchability and meltability increased by $7.5 \%, 25 \%$ and $23.6 \%$ in $0.02 \%$ TG cheese and by $13.3 \%, 37.5 \%$ and $32.7 \%$ in $0.05 \%$ TG cheese, respectively. Organoleptically, treated cheese was more acceptable than the control. According to the results, the use of $0.02 \%$ of the enzyme for full fat cheese and $0.05 \%$ for low fat cheese are recommended.

Keywords: Transglutaminase; Texture; Microstructure; Stretchability; Oiling off

\section{Metwally MME, El-Zeini HM* and Gazar EF}

Department of Dairy Technology, Faculty of Agriculture, Cairo University, Giza, Egypt

\section{*Corresponding author: El-Zeini HM \\ Đ dr_hodazeini@yahoo.co}

Department of Dairy Technology, Faculty of Agriculture, Cairo University, Giza, Egypt.

\section{Tel: 00201000752906}

\section{Citation: Metwally MME,}

El-Zeini HM, Gazar EF (2018) Impact of Using Transglutaminase Enzyme in Manufacturing Low and High Fat Mozzarella Cheese. J Food Nutr Popul Health Vol.2 No.1:5

Received: February 27, 2018; Accepted: March 22, 2018; Published: March 26, 2018

\section{Introduction}

Mozzarella cheese has unique functionalities in melted state as meltability, free oil formation, stretchability and browning [1]. These functionalities are governed by various factors such as milk composition, added additives, processing steps and storage conditions [2-4]. For proper mozzarella characteristics, a balance should exist between salt and $\mathrm{Ca}^{++}$as well as the presence of proper cheese $\mathrm{pH}[5,4]$. Mozzarella microstructure is formed of protein fibers with channels filled with cheese serum containing fat globules which allow more serum to exist particularly when fibers are closely packed. So, if fat is reduced as in low fat mozzarella, it becomes difficult to maintain the same water-toprotein ratio in the cheese and fat no longer acts as blocking agent. Therefore, the presence of proper percent of water is important, since it acts as lubricant or plasticizer between protein molecules.

The popularity of pizza widened Mozzarella cheese market. However, large consumption of pizza with regular fat Mozzarella caused the consumer concern about the consumption of high fat product. This led scientists to investigate the possibility of production of low fat Mozzarella. But low fat Mozzarella has inferior organoleptic and physical properties. Cheese with less than $10 \%$ fat usually has hard, rubbery and translucent with poor flavor development and poor meltability and performance when cooked on pizzas [5-7]. Number of measures were tried to overcome the problem either by modifying processing procedure or by adding certain additives such as whey proteins or fat replacer.

Currently, transglutaminase (TG) is the only commercial covalent cross linking enzyme available for improving dairy products. Cross-linking reactions may lead to a modification of functional properties of proteins such as solubility, emulsifying capacity, foaming and gelation properties. For example, in Quarg cheese, TG resulted in lower firmness, less grainy and creamier cheese $[6,8]$. In low fat ice-cream, TG produced superior physical and organoleptic properties [9]. In spite of that the use of TG in processing mozzarella cheese would improve the properties of full fat and helps in ameliorating low fat cheese physical problems, the enzyme hampers the coagulation process as TG cross links casein micelles molecules. Besides, the enzyme blocks the first stage of the coagulation by reducing the accessibility 
of rennet to break K-casein through its covalent bridges. This challenges the scientists to find a way to overcome that problem [6]. Number of workers has tackled the above problem. Some added the rennet into cold milk followed by the enzyme [10]. Others added the rennet for 5 min followed by the enzyme [11]. Ya-nan et al. [12] added the enzyme $7 \mathrm{~min}$ after rennet addition in processing low fat cheddar cheese. Ozer et al. [13] added the enzyme and rennet simultaneously at $30^{\circ} \mathrm{C}$. This research was carried out to adopt a method for using TG in making low and high fat mozzarella cheese.

\section{Materials and Methods}

\section{Materials}

Fresh raw cow milk was obtained from Dairy Science and Technology Department, Faculty of Agriculture, Cairo University, Giza, Egypt. Milk chemical composition used for high fat cheese was $11.54 \%, 3.0 \%, 3.38 \%, 2.68 \%$ and $0.22 \%$ for total solids, fat, protein, casein and NPN, respectively. Titratable acidity (\%) and casein/fat ratio (C/F) were $0.17 \%$ and 0.88 , respectively. Low fat cheese was made from milk with a composition of $9.96 \%, 1.3 \%$, $3.42 \%, 2.67 \%$ and $0.22 \%$ for total solids, fat, protein, casein and NPN, respectively. Milk titratable acidity (\%) was $0.16 \%$ and $\mathrm{C} / \mathrm{F}$ ratio was 20.05. Streptococcus thermophilus, Lactobacillus dilbruckii subsp. bulgaricus and calf rennet powder were obtained from Hansen's laboratory (Denmark). Transglutaminase was a gift from Ajinomoto Europe Sales Gmbh, Hambury. The powder preparation contains a 100 units/g. Dry coarse commercial sodium chloride was obtained from El-Nasr Co., Alexandria, Egypt.

\section{Selecting a method for milk coagulation with rennet in the presence of TG}

Seven trials with two different mixing orders of the two enzymes (TG and rennet) were tried (Table, 1) [14]. The first order was the addition of rennet into milk at $5^{\circ} \mathrm{C}$ and after $30 \mathrm{~min}$ TG was added and the mixture was kept either for $2\left(T_{2}\right)$ or $4\left(T_{3}\right)$ hours before raising the temperature to $40^{\circ} \mathrm{C}$ for coagulation. In the second order of mixing rennet and TG were added together to milk at $5^{\circ} \mathrm{C}$. The mixture was kept at $5^{\circ} \mathrm{C}$ for different periods of 2,4 and 5 hours for trials $\left(T_{4}\right),\left(T_{5}\right)$, respectively before raising the temperate to $40^{\circ} \mathrm{C}$. In trial (7) TG enzyme was added at $5^{\circ} \mathrm{C}$ for different periods from 2 to 5 hours, then rennet was added and the mix was left for $30 \mathrm{~min}$ before raising the temperature to $40^{\circ} \mathrm{C}$.

\section{Mozzarella cheese making with TG using the selected method}

Mozzarella cheese was manufactured according to the method of Kindstedt [15]. Fresh cow milk with 1.3 or $3 \%$ fat was standardized to the proper $\mathrm{c} / \mathrm{f}$ ratio for low and regular fat cheese (Table 1) and pasteurized at $72^{\circ} \mathrm{C}$ for $15 \mathrm{~s}$. Two percent starter was added to milk at $37^{\circ} \mathrm{C}$ and was left for $30 \mathrm{~min}$ for ripening. At $\mathrm{pH}$ of 6.45 , milk was cooled down to $5^{\circ} \mathrm{C}, 0.04 \%$ rennet was added and was left for $30 \mathrm{~min}$. The enzyme TG $(0.02$ or $0.05 \%)$ was mixed in and the mixture was kept for $2 \mathrm{~h}$ at the $5^{\circ} \mathrm{C}$ then the temperature was raised to $40^{\circ} \mathrm{C}$ for coagulation. The proper coagulum was cut by the two knives and curd particles were scalded at $42^{\circ} \mathrm{C}$. Whey drainage was at $\mathrm{pH} 6.1$ and cheddaring was carried out up to $\mathrm{pH}$ 5.9 followed by milling. Curd stretching was carried out in water at $70^{\circ} \mathrm{C}$. Cheese brining was carried out in $10 \%$ brine solution at $5^{\circ} \mathrm{C}$. Cheese was stored at $5^{\circ} \mathrm{C}$ for 28 days and sampled every week for analysis.

\section{Chemicals analysis}

Cheese moisture, titratable acidity, salt were determined according to AOAC [16]. Fat content was determined according to Ling [17]. Total nitrogen (TN), soluble nitrogen (SN), casein (CN) and non-protein nitrogen (NPN) were determined by semimicrokjeldahl method of SMEDP [18].

\section{Functional properties}

Meltability of cheese was measured using the meltability test according to Olson and Price [19] with the modification of Rayan et al. [20]. Stretchability was measured using an iron bar test as reported by Davis [21]. Free oil formation was estimated by modified Gerber test as described by Kindstedt and Fox [22]. Fat leakage was evaluated as described by Bertola et al. [23].

\section{Viscosity measurements}

Milk viscosity measurements on renneting were carried out in triplicates using a Brookfield viscometer (Model Dn-11+ Brookfield Engineering Lab., USA) according to Metwally and El-Zeini [24].

\section{Texture properties}

Texture parameters of coagulum were evaluated using texture analyzer (CNS Farnell, Borehamwoad, Hertfordshimer, England), as described by Ahmed et al. [25]. Cheese cubes of $10.0 \pm 0.1$ $\mathrm{mm}$ were submitted to two successive compressions to $50 \%$ of their initial height using flat-headed plunger ( $20 \mathrm{~mm}$ diameter) at a constant rate $0.5 \mathrm{~mm} / \mathrm{s}$. Samples were allowed to equilibrate at ambient temperature approximately 30-45 min prior to testing. Texture characteristics such as hardness, cohesiveness, springiness, Adhesiveness, Modulus of elasticity, gumminess and chewiness were calculated. Average of four measurements was reported.

\section{Cheese microstructure}

Cheese cubes were prepared according to Lobato-Calleros et al. [26]. Samples were examined at $5 \mathrm{KV}$ through Scanning Electron Microscope (JEOL-jsm 5200) equipped with an IBM-compatible computer to record the images.

Table 1 Mixing trials of milk with rennet \& TG and coagulation conditions.

\begin{tabular}{|c|c|}
\hline $\begin{array}{c}\text { Trials } \\
\text { T1 (control) }\end{array}$ & Method of mixing milk with rennet and $\mathrm{TG}^{1}$ \\
\hline $\mathrm{T} 2$ & Milk+rennet at $5{ }^{\circ} \mathrm{C} / 30 \mathrm{~min}$ \\
\hline $\mathrm{T} 3$ & Milk+rennet at $5^{\circ} \mathrm{C} / 30 \mathrm{~min}+\mathrm{TG}$ at $5^{\circ} \mathrm{C} / 2$ hours \\
\hline $\mathrm{T} 4$ & Milk+rennet at $5^{\circ} \mathrm{C} / 30 \mathrm{~min}+\mathrm{TG}$ at $5^{\circ} \mathrm{C} / 4$ hours \\
\hline $\mathrm{T} 5$ & Milk+rennet+TG simultaneously at $5^{\circ} \mathrm{C} / 2$ hours \\
\hline $\mathrm{T} 6$ & Milk+rennet+TG simultaneously at $5^{\circ} \mathrm{C} / 4$ hours \\
\hline $\mathrm{T} 7$ & Milk+TG $5^{\circ} \mathrm{C} / 2$ - 5 hours \\
\hline $0.04 \%(\mathrm{w} / \mathrm{v})$ & rennet and $0.05 \% \mathrm{TG}$. Coagulation temperature was $40^{\circ} \mathrm{C}$ \\
\hline
\end{tabular}




\section{Milk components recovery and yield calculations}

The actual percentage of fat and protein recovered in cheese or lost in whey and stretching water were calculated as percentage of that in milk. Theoretical yield was calculated with the modified Van Slyke formula as described by Metzger et al. [27].

Yield ( $\mathrm{kg}$ of cheese $/ 100 \mathrm{~kg}$ of milk $)=[(0.58 \times$ milk fat $\%)+($ milk casein\%-0.1)×1.13]/1-(cheese moisture/100).

Yield efficiency=(Actual yield/theoretical yield $) \times 100$.

\section{Organoleptic properties}

The cheese samples were organoleptically evaluated, by dairy Dept. staff members, according to the method of Scott [28]. Score points for flavor, body, textures and appearance were 50, 35 , and 15 , respectively.

\section{Statistical analysis}

Experiments were conducted in triplicate as a completely randomized design. Statistical analysis, ANOVA, was performed using MSTAT-C (ver2.10, Michigan state university, USA) package on a personal computer. Individual comparisons, contrast or LSD between treatments and correlations were also performed. Significance was declared at $P \leq 0.05$.

\section{Results and Discussion}

\section{The use of TG in rennet coagulation of milk}

Seven experimental trials (Table 1 ) were carried out using the fact that rennet and TG enzymes work at cold temperature $\left(5^{\circ} \mathrm{C}\right)$ but without casein coagulation. Coagulation process was monitored by viscosity measurements. Figure 1 illustrates viscosity changes profile by time during milk coagulation with rennet. Normal milk coagulation started with a moderate increase in viscosity then suffered a slight dip after which viscosity increased sharply to its peak at complete coagulation. Finally viscosity dropped due to coagulum deformation by shearing. The slight dip in viscosity encountered at the beginning of coagulation could be due to the decrease in size of the micelles by the removal of the hairy macropeptide of K-casein by rennet. O'Sullivan et al. [29] reported that TG through the covalent cross linking bridges blocks the primary coagulation step probably by reducing the accessibility of K-casein to rennet.

Mixing order of both enzymes affected the process and period of coagulation as well as the properties of the resulted gel. If TG was added to milk at $5^{\circ} \mathrm{C}$ prior to rennet addition, no coagulation will take place $\left(T_{7}\right.$, not shown). This could be as a result of casein polymerization with TG, a matter which prevented the accessibility of K-casein for rennet reaction and conferred some stability against casein precipitation with $\mathrm{ca}^{++}$. Milk coagulation occurred when rennet worked on casein either before TG addition or when both enzymes were added together to work simultaneously for a proper period of time.

Figure 1 shows that coagulation period was minimum (35 min) for $\left(T_{2}\right)$ in which rennet worked first for 30 min before the addition of TG. This was followed by $\left(T_{4}\right)$ at 49 min which both enzymes were added simultaneously and incubated for $2 \mathrm{hr}$. On the other hand, $T_{3}, T_{5}$ and $T_{6}$ took longer coagulation periods (58, 64 and 63.4 min, respectively).

These results indicated that, whether rennet works before TG $\left(T_{3}\right)$ or both worked simultaneously $\left(T_{4}\right.$ and $\left.T_{5}\right)$ there was a certain limit for the extent of TG reaction, which was not more than 2 $h$, otherwise coagulation is delayed or inhibited and forming abnormal viscosity curves. There was a positive correlation (0.973) between TG reaction period and coagulation period. This delayed coagulation was due to excessive TG linking of peptides [29]. The changes in texture of the six coagulums showed statistical significant $(P<0.001)$ differences in the texture parameters due to the reaction of TG and the mixing order of both enzymes. Penetration test showed that gel of $\mathrm{T}_{2}$ was higher in hardiness,

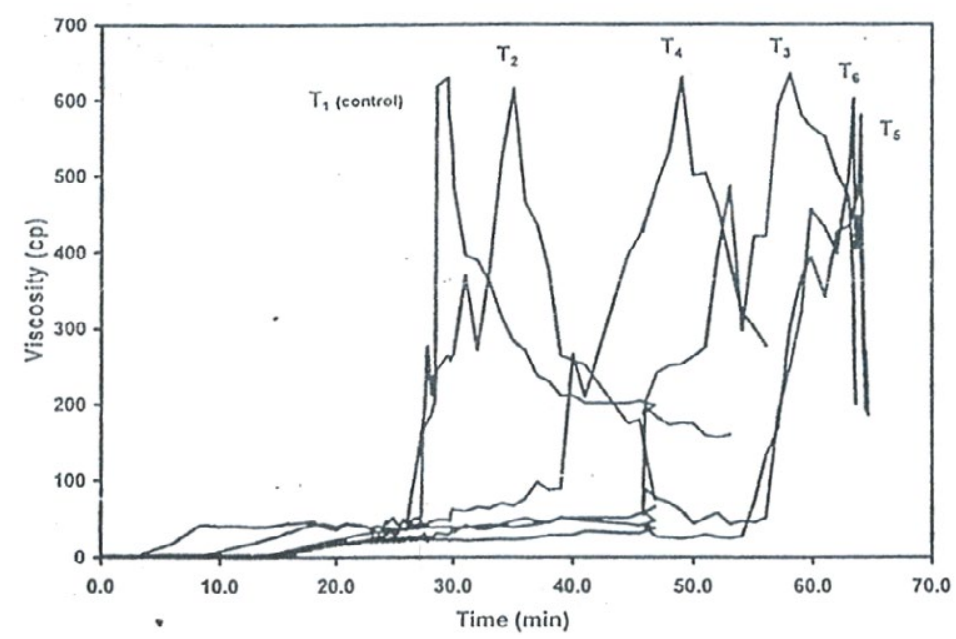

Figure 1 The effect of mixing methods of rennet \& TG with milk on viscosity during coagulation process. $\mathrm{T} 1=\mathrm{Milk}+\mathrm{rennet}$ at $5^{\circ} \mathrm{C} / 30$ min, $\mathrm{T} 2=$ Milk+rennet at $5^{\circ} \mathrm{C} / 30 \mathrm{~min}+\mathrm{TG}$ at $5^{\circ} \mathrm{C} / 2$ hours, $\mathrm{T} 3=$ Milk+rennet at $5^{\circ} \mathrm{C} / 30 \mathrm{~min}+\mathrm{TG}$ at $5^{\circ} \mathrm{C} / 4$ hours, T4=Milk+rennet+TG simultaneously at $5^{\circ} \mathrm{C} / 2$ hours, $\mathrm{T} 5=$ Milk+rennet+TG simultaneously at $5^{\circ} \mathrm{C} / 4$ hours, T6=Milk+rennet+TG simultaneously at $5^{\circ} \mathrm{C} / 5$ hours. 
adhesiveness, consistency, cohesiveness and gumminess than that of control and of $T_{3}$ and $T_{4}$ treatments. The values of the above parameters for $\mathrm{T}_{2}$ were 26.16, 6.5, 24, 20 and 50 and 18, $6,17.5,18$ and 31 for the control, respectively. The differences in hardness and consistency between $\mathrm{T}_{2}$ and other gels particularly of $T_{3}$ and the control were significant $(P<0.05)$. The differences between $T_{3}$ and $T_{4}$ were insignificant $(P<0.05)$. Bond strength of $\mathrm{T}_{2}$-gel was significantly higher than other trials; therefore mixing method of $\mathrm{T}_{2}$ was used for manufacturing mozzarella cheese. These results were in accordance with those of Han et al. [30].

\section{Mozzarella cheese processing}

Two experimental, high and low fat Mozzarella cheeses were processed from cow milk using two levels of TG $(0.02$ and 0.05 $\%, w t / w t)$, following the coagulation conditions of $T_{2}$ treatment (Table 1). The mean cheese composition changes as a function of TG and cold storage are shown in Table 2.

The enzyme treated cheese contained higher fat, moisture and TN and lower SN/TN and NPN/TN than their corresponding controls. The effect was enzyme concentration dependent. In low fat cheese, the increase in moisture and fat/DM was significant $(P<0.001)$ only at the $0.05 \%$ TG level but in high fat cheese the increase was significant at both TG levels. The increase in TN by TG was significant at both enzyme levels in low fat, but was significant only at the $0.05 \%$ T.G in high fat cheese $(P<0.001)$.
The decreasing effect on SN/TN and NPN/TN by the enzyme was significant at the enzyme both levels and in both cheeses. The enzyme did not affect cheese $\mathrm{pH}$ or acidity. In full fat cheese, the moisture, fat and TN increased from 52.16, 40.76 and 3.37 in the control into $52.74,41.12$ and $3.42 \%$ in the $0.02 \%$ TG and 53.13 , 41.32 and $3.48 \%$ in the $0.05 \%$ TG, respectively.

In low fat cheese, moisture, fat and TN increased from 54.48, 21.16 and $3.88 \%$ in the control into $54.71,21.46$ and $3.96 \%$ in the $0.02 \%$ TG cheese and 55.10, 21.90 and $3.99 \%$ in the $0.05 \%$ TG cheese, respectively.

During the 28 days of cold storage, cheese moisture decreased while acidity, TN, SN/TN and NPN/TN increased. On the other hand, Fat/DM of low fat cheese increased in the control and TG cheeses, and the increase was significant at the $0.05 \%$ TG $(P<0.001)$

In the high fat cheese, Fat/DM decreased in the control as well as in TG cheeses, but still TG cheese had higher fat than the control, and the difference was significant at the $0.05 \%$ TG level. Soluble and NPN/TN, increased on storage with the control more than TG-cheeses.

The enzyme, through cross-linking casein micelles, formed strong gel which retained more moisture, fat and protein and reduced the formation of fine curd particles which usually produces from weak curd. Moreover, the enzyme linked some small peptides

Table 2 Chemical composition changes during cold storage and functional properties of Mozzarella cheese made with transglutaminase enzyme

\begin{tabular}{|c|c|c|c|c|c|c|c|c|}
\hline & \multicolumn{4}{|c|}{ High fat cheese } & \multicolumn{4}{|c|}{ Low fat cheese } \\
\hline \multicolumn{9}{|c|}{ Storage period, days } \\
\hline Treatment & Fresh & 7 & 14 & 28 & Fresh & 7 & 14 & 28 \\
\hline \multicolumn{9}{|c|}{ Moisture } \\
\hline Control & $52.16^{c}$ & $51.81^{d}$ & $51.29^{e}$ & $50.18^{h}$ & $54.48^{b}$ & $53.78^{\mathrm{cd}}$ & $53.40^{\mathrm{de}}$ & $52.26^{h}$ \\
\hline $0.02 \%$ TG & $52.74^{b}$ & $52.35^{c}$ & $51.79^{d}$ & $50.71^{g}$ & $54.71^{\mathrm{ab}}$ & $54.02^{c}$ & $53.67^{c d}$ & $52.54^{\mathrm{gh}}$ \\
\hline $0.05 \% \mathrm{TG}$ & $53.13^{a}$ & $52.70^{\mathrm{b}}$ & $52.15^{c}$ & $50.98^{f}$ & $55.10^{a}$ & $54.42^{b}$ & $54.05^{c d}$ & $52.87^{\mathrm{fg}}$ \\
\hline \multicolumn{9}{|c|}{ Fat/DM } \\
\hline Control & 40.76 & 40.95 & 40.99 & $40.61^{f}$ & $21.61^{i}$ & $21.23^{\mathrm{hi}}$ & $21.5^{\mathrm{fgh}}$ & $21.68^{\mathrm{efg}}$ \\
\hline $0.02 \% \mathrm{TG}$ & $41.12^{\mathrm{abc}}$ & $41.21^{\mathrm{ab}}$ & $41.20^{\mathrm{ab}}$ & 40.71 & $21.46^{\mathrm{ghi}}$ & $21.61^{\mathrm{fg}}$ & $21.81^{\text {ef }}$ & $22.01^{\text {de }}$ \\
\hline $0.05 \%$ TG & $41.32^{\mathrm{a}}$ & 41.08 & $41.17^{\mathrm{ab}}$ & 40.66 & $21.90^{\mathrm{ef}}$ & $22.26^{\mathrm{cd}}$ & $22.46^{b}$ & $23.08^{a}$ \\
\hline \multicolumn{9}{|c|}{ Acidity } \\
\hline Control & $0.67^{\mathrm{fgh}}$ & 0.72 & $0.75^{\text {de }}$ & $0.86^{\mathrm{ab}}$ & $0.64^{\text {th }}$ & $0.68^{\mathrm{efg}}$ & $0.72^{\text {def }}$ & $0.85^{\mathrm{a}}$ \\
\hline $0.02 \%$ TG & $0.63^{h}$ & $0.67^{\mathrm{fgh}}$ & $0.73^{\text {def }}$ & $0.84^{\mathrm{ab}}$ & $0.6^{\text {th }}$ & $0.66^{\mathrm{fgh}}$ & $0.7^{1}$ & $0.83^{\mathrm{ab}}$ \\
\hline $0.05 \% \mathrm{TG}$ & $0.62^{h}$ & $065^{\text {gh }}$ & $0.71^{\text {efg }}$ & $0.83^{\mathrm{abc}}$ & $0.60^{h}$ & $0.64^{\mathrm{gh}}$ & $0.69^{\text {efg }}$ & $0.81^{a b c}$ \\
\hline \multicolumn{9}{|c|}{ TN } \\
\hline Control & $3.37^{\mathrm{h}}$ & $3.40^{\mathrm{gh}}$ & $3.43^{\mathrm{fgh}}$ & 3.52 & $3.88^{\mathrm{h}}$ & $3.91^{\mathrm{gh}}$ & $3.94^{\mathrm{fgh}}$ & 4.01 \\
\hline $0.02 \%$ TG & $3.42^{\mathrm{fgh}}$ & $3.45^{\mathrm{efg}}$ & 3.49 & $3.58^{\mathrm{ab}}$ & $3.96^{\mathrm{efg}}$ & $4.02^{\text {cde }}$ & $4.05^{\mathrm{bcd}}$ & $4.11^{\mathrm{ab}}$ \\
\hline $0.05 \%$ TG & 3.48 & 3.52 & $3.54^{b c}$ & $3.62^{\mathrm{a}}$ & $3.99^{\text {def }}$ & $4.05^{\mathrm{bcd}}$ & $4.08^{\mathrm{abc}}$ & $4.14^{a}$ \\
\hline \multicolumn{9}{|c|}{ SN/TN } \\
\hline Control & $4.43^{m}$ & $5.40^{\mathrm{i}}$ & $6.97^{g}$ & $10.11^{\mathrm{a}}$ & $3.65^{\ell}$ & $4.09^{j}$ & $5.33^{\mathrm{g}}$ & $8.48^{a}$ \\
\hline $0.02 \%$ TG & $4.27^{n}$ & $5.13^{k}$ & $6.60^{h}$ & $9.71^{b}$ & $3.37^{\mathrm{m}}$ & $3.73^{k}$ & $5.17^{h}$ & $7.49^{b}$ \\
\hline $0.05 \%$ TG & $4.05^{\circ}$ & $4.99^{1}$ & $6.31^{i}$ & $9.09^{c}$ & $3.25^{n}$ & $3.19^{n}$ & $4.97^{i}$ & $7.14^{c}$ \\
\hline \multicolumn{9}{|c|}{ NPN/TN } \\
\hline Control & $2.14^{j}$ & $2.54^{h}$ & $2.95^{g}$ & $4.60^{\mathrm{a}}$ & $1.90^{\mathrm{i}}$ & $2.16^{h}$ & $2.52^{f}$ & $3.84^{a}$ \\
\hline $0.02 \%$ TG & $2.05^{k}$ & $2.31^{i}$ & $2.52^{\mathrm{h}}$ & $4.18^{b}$ & $1.75^{\mathrm{j}}$ & $1.96^{i}$ & $2.34^{\mathrm{g}}$ & $3.40^{b}$ \\
\hline $0.05 \%$ TG & $1.95^{\prime}$ & $2.17^{j}$ & $2.38^{i}$ & $4.01^{c}$ & $1.55^{k}$ & $1.78^{j}$ & $2.18^{h}$ & $3.25^{c}$ \\
\hline
\end{tabular}


with the micelles and retained others within curd pockets; this reduces the soluble and non-protein nitrogen as shown in Table 2.

\section{Protein and fat loss in whey stretch water and cheese yield}

Table 3 presents the effect of TG on cheese yield and milk components recovery. The enzyme increased cheese yield and reduced protein and fat lost in whey and stretch water. In high fat cheese the yield increased from $12 \%$ to $12.9 \%$ and $13.60 \%$ on using the 0.02 and $0.05 \%$ TG, respectively. In low fat cheese, the yield increased from $9.90 \%$ to $10.70 \%$ and $11.40 \%$ on using the 0.02 and $0.05 \% \mathrm{TG}$, respectively.

Retaining more milk components in the cheese as well as the reduction in protein \& fat loss in whey and stretch water resulted in higher cheese yield (Table 3). The increase in cheese yield was enzyme concentration dependent. In high fat cheese, the increase in yield was significant $(P<0.001)$ only at the $0.05 \%$ TG level, but in low fat cheese both enzyme levels led to significant yield increase.

\section{Cheese organoleptic evaluation}

Organoleptically, both TG cheeses were improved than their corresponding controls. In the high fat cheese, the use of $0.02 \%$ TG level was preferred by the panelists scoring (93/100) while cheese with $0.05 \%$ TG was too soft and scored (89/100). On the other hand, low fat cheese with $0.05 \%$ TG was preferred than $0.02 \%$ TG cheese, their scores were $(85 / 100)$ and $(83 / 100)$, respectively.

\section{Cheese functional properties}

The functional characteristics of mozzarella cheese treated with TG and their change during cold storage are reported in Table 4. In low and high fat cheese, the enzyme improved cheese stretchability, meltability, oiling off and fat leakage and the degree of improvement was enzyme concentration dependent. The increase in stretchability and meltability was significant $(P<0.001)$ at both TG concentration. On the other hand, the decrease in oiling off and fat leakage was significant only at the 0.05 TG level.

Table 3 The effect of TG on cheese yield and protein \& fat loss in whey stretch water.

\begin{tabular}{|c|c|c|c|c|c|c|}
\hline \multicolumn{7}{|c|}{ Type of cheese } \\
\hline \multicolumn{4}{|c|}{ High fat } & \multicolumn{3}{|c|}{ Low fat } \\
\hline \multicolumn{7}{|c|}{ TG, \% } \\
\hline & Control & 0.02 & 0.05 & Control & 0.02 & 0.05 \\
\hline Cheese yield \% & $12.00^{\mathrm{b}}$ & $12.90^{\mathrm{ab}}$ & $13.60^{\mathrm{a}}$ & $9.90^{c}$ & $10.70^{\mathrm{b}}$ & $11.40^{\mathrm{a}}$ \\
\hline \multicolumn{7}{|c|}{ Components lost in whey, \% } \\
\hline Protein & $27.58^{\mathrm{a}}$ & $20.35^{b}$ & $15.09^{b}$ & $22.91^{\mathrm{a}}$ & $16.03^{b}$ & $9.94^{c}$ \\
\hline Fat & $18.48^{\mathrm{a}}$ & $15.39^{b}$ & $13.23^{c}$ & $14.50^{\mathrm{a}}$ & $12.33^{b}$ & $9.24^{c}$ \\
\hline \multicolumn{7}{|c|}{ Components lost in stretch water, \% } \\
\hline Protein & $0.53^{\mathrm{a}}$ & $0.26^{\mathrm{b}}$ & $0.18^{b}$ & $0.71^{\mathrm{a}}$ & $0.53^{b}$ & $0.27^{c}$ \\
\hline Fat & $7.62^{\mathrm{a}}$ & $5.31^{\mathrm{b}}$ & $3.0^{c}$ & $7.00^{\mathrm{a}}$ & $4.00^{b}$ & $2.70^{c}$ \\
\hline
\end{tabular}

Table 4 Functional properties of Mozzarella cheese made with transglutaminase enzyme.

\begin{tabular}{|c|c|c|c|c|c|c|c|c|}
\hline & \multicolumn{4}{|c|}{ High fat cheese } & \multicolumn{4}{|c|}{ Low fat cheese } \\
\hline \multicolumn{9}{|c|}{ Storage period, days } \\
\hline Treatment & Fresh & 7 & 14 & 28 & Fresh & 7 & 14 & 28 \\
\hline \multicolumn{9}{|c|}{ Stretchability $(\mathrm{cm})$} \\
\hline Control & $160^{n}$ & $170^{m}$ & $183^{i}$ & $233^{f}$ & $100^{m}$ & $119^{\prime}$ & $134^{k}$ & $179^{f}$ \\
\hline $0.02 \% \mathrm{TG}$ & $200^{k}$ & $210^{j}$ & $223^{g}$ & $259^{c}$ & $140^{j}$ & $153^{i}$ & $174^{\mathrm{g}}$ & $214^{b}$ \\
\hline $0.05 \% \mathrm{TG}$ & $220^{h}$ & $234^{f}$ & $247^{d}$ & $278^{a}$ & $160^{h}$ & $174^{\mathrm{g}}$ & $189^{e}$ & $223^{a}$ \\
\hline \multicolumn{9}{|c|}{ Meltability (mm) } \\
\hline Control & $55^{f}$ & $63^{\mathrm{ef}}$ & 72 & $87^{a b c}$ & $30^{k}$ & $42^{j}$ & $57^{g}$ & $77^{c}$ \\
\hline $0.02 \% \mathrm{TG}$ & $68^{\text {def }}$ & 75 & 80 & $93^{\mathrm{ab}}$ & $45^{i}$ & $57^{g}$ & $69^{d}$ & $85^{b}$ \\
\hline $0.05 \% \mathrm{TG}$ & 73 & 81 & 86 & $100^{\mathrm{a}}$ & $50^{\mathrm{h}}$ & $61^{f}$ & $77^{c}$ & $92^{\mathrm{a}}$ \\
\hline \multicolumn{9}{|c|}{ Oiling off (\%) } \\
\hline Control & $4.25^{e}$ & $4.42 \mathrm{de}$ & $4.78^{c}$ & $5.70^{\mathrm{a}}$ & $1.72^{\mathrm{kl}}$ & $1.89^{\mathrm{hi}}$ & $2.15^{f}$ & $3.05^{\mathrm{a}}$ \\
\hline $0.02 \% \mathrm{TG}$ & $4.22^{\mathrm{e}}$ & $4.35 d^{e}$ & $4.63^{\text {cd }}$ & $5.63^{\mathrm{a}}$ & $1.65^{\mathrm{Im}}$ & $1.82^{\mathrm{ij}}$ & $2.02^{\mathrm{g}}$ & $2.98^{\mathrm{ab}}$ \\
\hline $0.05 \% \mathrm{TG}$ & $4.22^{\mathrm{e}}$ & $4.33 d^{e}$ & $4.59^{\text {cd }}$ & $5.58^{\mathrm{a}}$ & $1.63^{m}$ & $1.77^{\mathrm{jk}}$ & $1.94^{h}$ & $2.95^{b}$ \\
\hline \multicolumn{9}{|c|}{ Fat leakage (mm) } \\
\hline Control & $57^{\mathrm{h}}$ & $64^{f}$ & $73^{\text {cd }}$ & $85^{a}$ & $38 g^{g h}$ & $64^{f}$ & $53^{d}$ & $67^{a}$ \\
\hline $0.02 \%$ TG & $55^{h}$ & $60^{g}$ & $68^{e}$ & $79^{b}$ & $36^{\mathrm{hi}}$ & $60^{g}$ & $49^{e}$ & $59^{b c}$ \\
\hline $0.05 \%$ TG & $51^{i}$ & $57^{h}$ & $64^{f}$ & $75^{c}$ & $30^{i}$ & $38^{\mathrm{gh}}$ & $45^{f}$ & $57^{c}$ \\
\hline
\end{tabular}


The improvement in the above parameters continued through cold storage, and the degree of significance between treatments was preserved through the 28 days of cold storage. In high fat cheese, stretchability increased from 160 in the control into 200 and $220 \mathrm{~cm}$ in 0.02 and $0.05 \%$ TG cheese, cheese meltability improved from 55 in the control into 48 and $73 \mathrm{~mm}$ in the 0.02 and $0.05 \%$ TG cheese, respectively.

The enzyme reduced the oiling off and fat leakage from 4.25 and 57 in the control into $4.22 \%$ and $51 \mathrm{~mm}$ in the $0.05 \%$ TG cheese, respectively. During cold storage all the above parameters increased but their improvement was preserved.

In low fat cheese, stretchability increased from $100 \mathrm{~cm}$ in the control cheese to 140 and $160 \mathrm{~cm}$, meltability increased from $30 \mathrm{~mm}$ in the control into 45 and $50 \mathrm{~mm}$ in the 0.02 and $0.05 \%$ TG cheeses, respectively. Oiling off decreased from $1.72 \%$ in the control cheese to 1.65 and $1.63 \%$ and fat leakage from $38 \mathrm{~mm}$ in the control to 36 and $35 \mathrm{~mm}$ in the 0.02 and $0.05 \%$ TG cheeses, receptively. The differences were significant only with the $0.05 \%$ TG cheese.

\section{Cheese texture}

Low fat cheese showed higher hardness, gumminess, modulus, adhesiveness, chewiness and springiness than high fat cheese (Figure 2). The use of TG enzyme increased the values of the above parameters and the increase was inversely proportional to TG concentration, in low and high fat cheese. However, cohesiveness and springiness were positively correlated in high and low fat cheese with TG concentration (Figure 2).

The enzyme caused texture modification through recovery of more whey, whey protein and fat within the curd and was kept by the formation of large number of bonds.

The interaction between the enzyme concentration and the texture resulted in good and acceptable texture and body with $0.02 \%$ TG in full fat cheese and the $0.05 \%$ in low fat cheese and this was clear in the microstructure observation and organoleptic properties.

\section{Cheese microstructure}

High fat: In the control, protein exhibited oriented fibrous structure forming linear fibers, serum channels existed between fibers containing fat globules. In the $0.02 \%$ TG, protein intercrossing formed closer net causing fat globules to surface the fibers giving smoother structure and richer structure.

Low fat: Control cheese had a continuous protein matrix with the strands having no particular orientation intercepted with serum pockets. In the $0.02 \% \mathrm{TG}$, cheese protein matrix intercrossed with no particular direction but with more compact fibrous. In the $0.05 \%$ TG, more oriented and more compact fibrous with more elongated holes of serum with the appearance of fat globules (Figure 3). This effect increased with $0.05 \%$ TG causing fibers to intersect in a circular form giving a more compact structure with the appearance of fat globules giving even softer body.

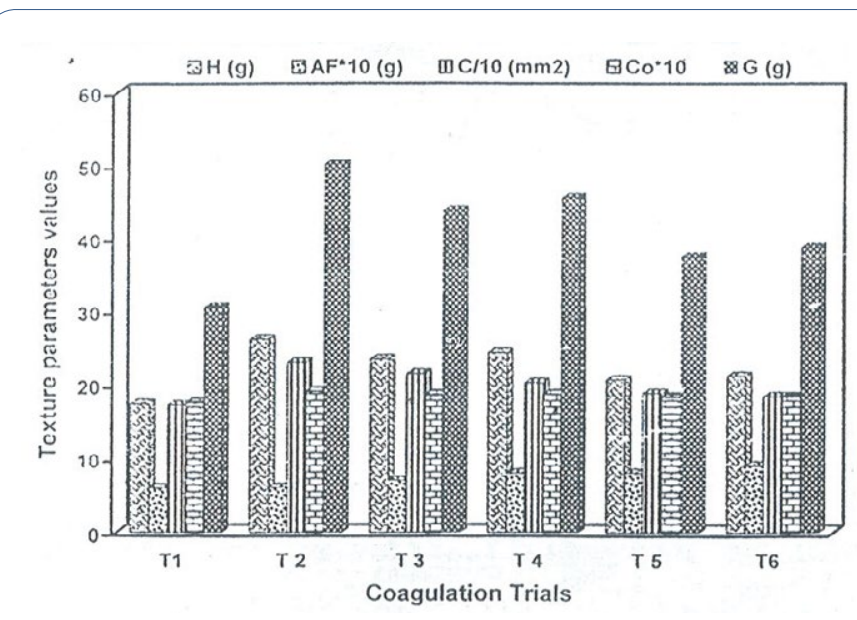

Figure 2 The effect of mixing methods of rennet \& TG with milk on texture parameters (Hardness $(\mathrm{H})$, Adhesiveness force (AF), Consistency (C), Cohesiveness (Co) and Gumminess $(G)$ of the coagula.

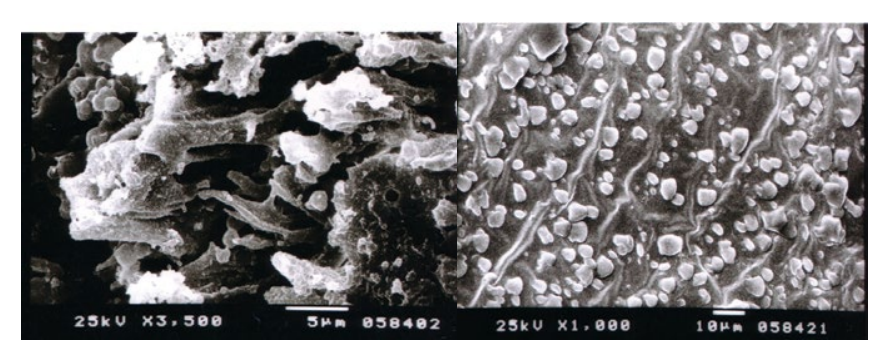

Control full fat Mozzarella cheese

Control low fat mozzarella cheese

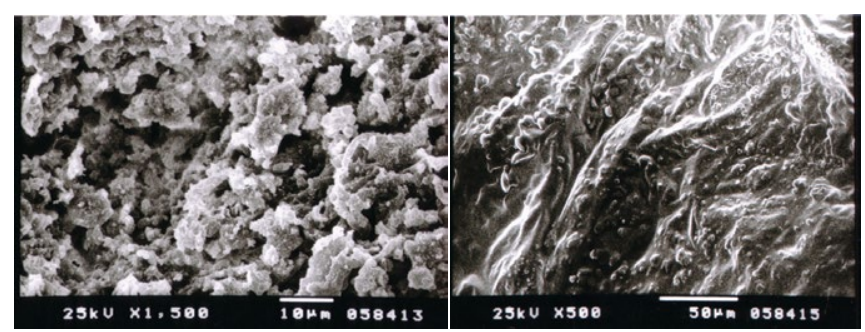

$0.2 \%$ TG full fat Mozzarella cheese $0.2 \%$ TG low fat mozzarella cheese

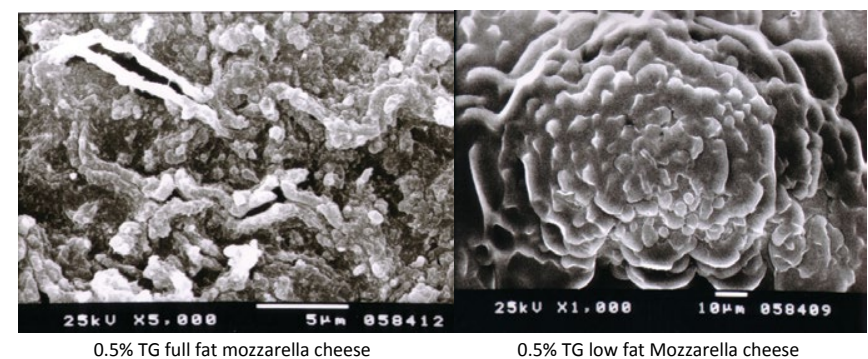

Figure 3 High (left) and low (right) fat Mozzarella cheese
micrographs: (a) control, (b) $0.02 \mathrm{TG}$ and (c) $0.05 \% \mathrm{TG}$.

\section{Conclusion}

The devised methods for using TG in rennet coagulated cheeses proved to be working. The first method was followed up for processing low and high fat Mozzarella cheese. TG enzyme cannot be added before rennet nor should the working time of the enzyme be longer than $2 \mathrm{~h}$. High fat Mozzarella cheese 
hardness, melting and stretchability properties were improved by using the enzyme. TG level of $0.02 \%$ gave the best results organoleptically as well as the other physical properties. Actually, the enzyme accentuates the effect of fat in cheese and increases the retention of more moisture. Both components helped cheese meltability and stretchability. The use of TG in making low fat Mozzarella modified cheese physical properties in a direction that ameliorate the bad effect of low fat. The enzyme at $0.05 \%$

\section{References}

1 Imm JY, Oh EJ, Han KS, Oh S, Park YW, et al. (2003) Functionality and Physico-Chemical Characteristics of Bovine and Caprine Mozzarella Cheeses during Refrigerated Storage. J Dairy Sci 86: 2790-2798.

2 Sheehan JJ, O'Sullivan MM, Guinee TP (2004) Effect of coagulation type and storage temperature on the functionality of reduced-fat Mozzarella cheese. Lait 84: 551-566.

3 Pastorino AJ, Ricks NP, Hansen CL, Mcmahon DJ (2003) Effect of calcium and water injection on structure-function relationships of cheese. J Dairy Sci 86: 105-113.

4 McMahon D, Oberg C (1999) Deconstructing Mozzarella. Dairy Industries Int 64: 23-26.

5 Guinee TP, Feeney EP, Auty MAE, Fox PF (2002) Effect of pH and Calcium Concentration on Some Textural and functional Properties of Mozzarella Cheese. J Dairy Sci 85: 1655-1669.

6 Jaros D, Partschefeld C, Henle T, Rohm H (2006) Transglutaminase in dairy products: chemistry, physics, applications. J Texture Stud 37: 113-155.

7 Badawi RM, Farag SI, Okasha Al, Omara GM (2004) Changes in rheological properties and microstructure during storage of low fat Mozzarella cheese. Egyptian. J Dairy Sci 32: 341-353.

8 Myllarinen P, Buchert J, Aution K (2007) Effect of transglutaminase on Rheological properties and microstructure of chemically acidified sodium caseinate gels. Int Dairy J 17: 800-807.

9 Metwally AMM (2007) Effect of enzymatic cross-linking of milk proteins on properties of ice-cream with different composition. Int J Food Sci Technol 42: 939-947.

10 Kumazawa Y, Miwa N (2005) Process for producing cheese curd. US Patent 0123645 Al.

11 Yuk Z, Avci E, erdem YK (2011) Modification of the renneting process in Berridge substrate by TG. Int J of dairy Tech 64: 365-372.

12 Ya-nan HU, Ke-Shan GE, Jiang L, Hui-yan GUO, Luo J, et al. (2013) Effects of TG yield, compositional, functional properties of low fat cheddar cheese. Food Sci Tech Res 19: 359-367.

13 Ozer BAA, Hayaloglu H, Gursoy AY (2013) Simultaneous use of TG enzyme and rennet in white brined cheese production. Int Dairy J 33: 129-134.

14 Gazar EFR (2007) The use of TG in processing low and high fat Mozzarella cheese. Ph.D Thesis, Dairy Technology Dept, Faculty of Agriculture, Cairo Univ, Egypt.

15 Kindstedt PS (1993) Mozzarella and pizza cheese. In: Cheese, concentration increased significantly cheese yield, moisture and the recovery of fat and whey proteins. The enzyme improved low fat Mozzarella meltability stretchability, oiling off and fat leakage. Organoleptically, treated cheese was more acceptable and the structure parameters were more satisfactory than the control. There results pointed out that when TG is used in dairy products, the proper concentration should be selected according to properties required.

Chemistry, Physics and Microbiology. 2: 337-362, Chapman and Hall Publ. Inc., London.

16 Association of Official Agriculture Chemists (1990) Official Methods of Analysis (AOAC), Arlington, VA.

17 Ling ER (1963) Dairy Chemistry (3rd edn.), Champman and Hall LTd. London.

18 Marshall RT (1985) Standard Methods for the Examination of Dairy Products. Amer Pub Health Assoc Washington, DC Egypt.

19 Olson NF, Price WV (1958) A melting test for pasteurized process cheese spreads. J Dairy Sci 41: 999-1000.

20 Rayan AA, Kalab M, Ernstrom CA (1980) Microstructure and rheology of process cheese Scanning Electron Microscopy. CF Dairy Sci Abstr 3: 635-643.

21 Davis JG (1966) Cheese. Made and printed by the White Friars Press LTD. London \& Tonbride, U.K.

22 Kindstedt PS, Fox PF (1991) Modified Gerber test for free oil in melted Mozzarella cheese. J Food Sci 56: 1115-1116.

23 Bertola NC, Califano AN, Bevilacqua AE, Zaritzky NE (1996) Effect of freezing conditions on functional properties of low moisture mozzarella cheese. J Dairy Sci 79: 185-190.

24 Metwally AMM, El-Zeini HM (2004) The effect of processing treatments of milk coagulation with rennet as measured by viscositytime curve. J Agric Sci Mansoura Univ 29: 3361-3374.

25 Ahmed HN, El Soda M, Hassan An, Frank J (2005) Improving the texture properties of an acid coagulated (Karish) cheese using exopolysaccharide producing cultures. Swiss Society of Food Science and Technology 38: 843-847.

26 Lobato-Calleros C, Ramos-Solis L, Santos-Moreno A, RodriguezHuezo ME (2006) Microstructure and texture of panela type cheeselike products: use of low methoxyl pectin and canola oil as milk-fat substitutes. Revista Mexicana De Ingenira Quimica 5: 71-79.

27 Metzger LE, Barbano DM, Rudan MA, Kindstedt PS (2000) Effect of milk pre-acidification on low fat mozzarella cheese I. Composition and yield. J Dairy Sci 83: 648-658.

28 Scott R (1981) Cheese making practice. Applied Sci pub ( $4^{\text {th }}$ edn.), Ltd. London.

29 O'Sullivan MM, Kelly AL, FOX PF (2002) Influence of transglutaminase treatment on some physico-chemical properties of milk. J Dairy Res 69: 433-442.

30 Han XO, Pfeifer JK, Lincourt RH, Schuerman JM (2003) Process for making a cheese product using transglutaminase. United States Patent No. Us 6,572,901 B2. 